\title{
OS RISCOS \\ DO MARKETING ESPORTIVO
}

Luis Fernando Pozzi

O produto "esporte" tem uma série de características únicas e imprevisíveis, dificultando as ações de marketing daqueles que o administram. Trata-se de um produto intangível, experimental e subjetivo, em que predomina a paixão e todos os nele envolvidos se consideram experts, dada a forte identificação pessoal com o produto. Além disso, o esporte tem um grande apelo global e, ao contrário das demais indústrias, não se pode matar a concorrência, pois os clubes dependem dos outros para participar das competições.

Não há dúvida de que nenhum outro produto chega perto do esporte quando o assunto é paixão. Afinal de contas, onde mais encon- traremos pessoas que são enterradas com a bandeira do clube sobre o caixão ou são cremadas e têm suas cinzas esparramadas sobre o campo?

Temos observado um número cada vez maior de empresas interessadas em investir no esporte para associar suas marcas a um produto de qualidade e que transmita uma série de conceitos positivos e que trazem maior qualidade de vida, como saúde, entretenimento, plasticidade, competitividade, emoção, alegria, etc. No entanto fatores inerentes e incontroláveis do esporte, como a imprevisibilidade advinda da performance do time ou dos atletas, o clima, os resultados, etc., vêm se juntar a outros fatores mais controláveis, como a desorganização administrativa, os calendários irracionais, a violência dentro e fora de campo, a baixa qualidade dos estádios, etc.

Esse conjunto de fatores pode acabar influenciando na decisão de muitas empresas que fazem um processo sério de avaliação das melhores oportunidades de investimento no esporte em vez de seguir unicamente as preferências pessoais do principal executivo da empresa. Talvez esse seja o motivo pelo qual as principais multinacionais ainda relutam em investir em nosso mercado esportivo, mesmo tendo um longo histórico de associação com o mercado norte-americano e europeu. No mo- 
mento, contam-se nos dedos das mãos tais empresas: Pirelli, Parmalat, GM, Cirio e Nike.

Há uma série de incidentes no esporte, assim como em qualquer outro ramo de atividade, que comprova que as empresas devem tomar medidas rápidas e eficientes de relações públicas para evitar estragos maiores em sua imagem. Que medidas deveriam ser tomadas, por exemplo, para atenuar a publicidade negativa resultante de um flagrante de doping ou qualquer outro ato indevido por parte de um atleta patrocinado por sua empresa, ou de um acidente durante uma competição com sua marca aparecendo com o atleta morto ou ferido, ou, ainda, da descoberta de que o clube patrocinado subornou outros jogadores ou árbitros?

O que não faltam são exemplos de episódios desse tipo. Um dos primeiros casos de que se tem notícia aconteceu em abril de 1995: depois de um jogo entre Palmeiras e Portuguesa, o ex-zagueiro palmeirense Tonhão chutou e pisou a camisa da Lusa, o que levou um dos diretores da Portuguesa na época, que era também diretor do Sindicato das Panificadoras de São Paulo, a propor um boicote aos produtos da Parmalat. A polêmica só não foi adiante porque José Carlos Brunoro, diretor de esportes da multinacional na época, se apressou em pedir mil desculpas.

Como uma das pioneiras do marketing esportivo no país e com seis anos de associação com o Palmeiras, a Parmalat teve de lidar com uma série de incidentes potencialmente danosos à sua marca:

- denúncias do suposto "Esquema Parmalat", complô em que a Parmalat usaria sua influência e seu poder financeiro para ser favorecida pela arbitragem;

- necessidade de domesticar o "animal" Edmundo, cujo tem- peramento explosivo e encrenqueiro batia de frente com a imagem que a empresa queria passar e a desgastava na hora em que o clube se utilizava de artifícios legais para anular as freqüentes suspensões do atleta;

- o vandalismo das torcidas organizadas, principalmente da "Mancha Verde", fez com que a Parmalat tivesse seu nome estampado nas páginas policiais em vez das esportivas;

- torcedores e alguns jogadores do Grêmio propuseram que se proibisse a venda de produtos Parmalat em seu estádio, revoltados com a arbitragem no último jogo das semifinais da Copa do Brasil de 1996 entre Palmeiras e Grêmio.

A mobilização dos donos de padaria se fez sentir novamente em 1998, numa tentativa de boicote de algumas panificadoras de São Paulo aos tíquetes da VR (patrocinadora do Campeonato Paulista) em protesto contra a atuação do árbitro argentino Javier Castrilli na semifinal entre Corinthians e Portuguesa.

O relacionamento entre o Corinthians e o Excel Econômico também teve seus momentos de turbulência na época em que tanto o técnico Luxemburgo como a diretoria culparam publicamente o patrocinador pela falta de empenho nas contratações de reforços ou quando se noticiavam atrasos no pagamento das cotas mensais do patrocinador ao clube.

Um episódio recente e de grande proporção, no entanto, foi a suposta interferência da Nike no diaa-dia da seleção brasileira durante a Copa do Mundo, que envolveria a escalação de jogadores e a obrigatoriedade contratual de que Ronaldinho participasse de todos os jogos. Após o episódio do mal-estar do maior garoto-propaganda da empresa no futebol antes da final da Copa, tal alegação poderia criar, na opinião pública, a impressão de que a Nike poderia estar pondo em risco a vida do atleta para garantir seus objetivos comerciais, o que traria um efeito devastador na imagem da empresa.

Não temos conhecimento de nenhuma pesquisa de avaliação do impacto da imagem da Nike no mercado brasileiro após essas denúncias, mas é fato concreto que a mídia especializada passou a criticar ainda mais a influência da empresa nos rumos da sagrada Seleção Nacional, o que gerou uma grande publicidade negativa.

Temos acompanhado uma série de publicações que louvam o marketing esportivo como uma das ferramentas de comunicação mais eficientes, modernas e subutilizadas em nosso mercado, com o que concordamos plenamente, mas parecenos importante olhar sempre o outro lado da moeda, para que os riscos sejam minimizados e os resultados práticos sejam ainda melhores.

Para tanto, é preciso que as empresas adotem medidas de relações públicas rápidas e transparentes, que visem a atacar o problema de frente, e não escondê-lo. Agindo dessa maneira, elas demonstrarão respeito por seus consumidores, aumentando a probabilidade de desassociar sua marca de um acontecimento negativo. $\bigcirc$

Luís Fernando Pozzi é Professor de Marketing Esportivo da EAESP/FGV e Autor do livro A grande jogada: teoria e prática do marketing esportivo. E-mail:lpozzi@fgvsp.br 